University of Nebraska - Lincoln

DigitalCommons@University of Nebraska - Lincoln

Genetic Improvement in Winter Wheat Yields in the Great Plains of North America, 1959-2008

\author{
Robert A. Graybosch \\ University of Nebraska-Lincoln, bob.graybosch@ars.usda.gov \\ C. James Peterson \\ Oregon State University
}

Follow this and additional works at: https://digitalcommons.unl.edu/usdaarsfacpub

Part of the Agricultural Science Commons

Graybosch, Robert A. and Peterson, C. James, "Genetic Improvement in Winter Wheat Yields in the Great Plains of North America, 1959-2008" (2010). Publications from USDA-ARS / UNL Faculty. 915. https://digitalcommons.unl.edu/usdaarsfacpub/915

This Article is brought to you for free and open access by the U.S. Department of Agriculture: Agricultural Research Service, Lincoln, Nebraska at DigitalCommons@University of Nebraska - Lincoln. It has been accepted for inclusion in Publications from USDA-ARS / UNL Faculty by an authorized administrator of DigitalCommons@University of Nebraska - Lincoln. 


\title{
Genetic Improvement in Winter Wheat Yields in the Great Plains of North America, 1959-2008
}

\author{
Robert A. Graybosch^ and C. James Peterson
}

\begin{abstract}
Data from USDA-coordinated winter wheat (Triticum aestivum L.) regional performance nurseries collected over the time period 1959 to 2008 were used to estimate genetic gain (loss) in grain yield, grain volume weight, days to heading, and plant height in winter wheats adapted to the Great Plains of North America. In both the Southern Regional (SRPN) and Northern Regional Performance Nurseries (NRPN), linear regression revealed significant positive relationships between relative grain yields of advanced breeding lines and calendar year of the nursery trial. The estimated genetic gain in grain yield potential since 1959 was approximately 1.1\% (of the control cultivar Kharkof) $\mathrm{yr}^{-1}$ for all entries in the SRPN, and $1.3 \% \mathrm{yr}^{-1}$ if only the most productive entry was considered. For the NRPN, the estimates of genetic gain in grain yield were $0.79 \% \mathrm{yr}^{-1}$ for all entries, and also $0.79 \% \mathrm{yr}^{-1}$ for the most productive entry. Linear regressions of relative grain yields vs. year over the time period 1984 to 2008, however, showed no statistically significant trend in the SRPN. For the same time period in the NRPN, a statistically significant positive slope of 0.83 was observed, though the coefficient of determination $\left(R^{2}\right)$ was only 0.28 . Relative grain yields of Great Plains hard winter wheats may have peaked in the early to mid1990s, and further improvement in the genetic potential for grain yield awaits some new technological or biological advance.
\end{abstract}

R.A. Graybosch, USDA-ARS, 137 Keim Hall, East Campus, Univ. of Nebraska, Lincoln, NE 68583. C.J.Peterson, Dep. of Crop and Soil Science, 109 Crop Science Building, Oregon State Univ., Corvallis, OR 97331. Mention of firm names or trade products does not imply that they are endorsed or recommended by the USDA or the University of Nebraska over other firms or products not mentioned. Received 25 Nov. 2009. *Corresponding author (bob.graybosch@ars.usda.gov).

Abbreviations: NRPN, Northern Regional Performance Nurseries; SRPN, Southern Regional Performance Nurseries.

I MPROVEMENT IN GRAIN YIELD is the primary breeding goal of all wheat breeding programs in the Great Plains of North America. Wheat breeding efforts in the Great Plains began in earnest in the 1920s (Reitz and Heyne, 1944). These efforts have allowed wheat producers in the region the achievement of remarkable increases in grain productivity. Feyerherm et al. (1984) estimated that approximately one-half of the gain in annual productivity in the region was due to genetic gain from wheat breeding programs.

Periodic evaluation of the rate of genetic gain in grain yield is important, as world population grown remains unchecked. Wheat is the world's third most important cereal crop, ranking behind only maize (Zea mays L.) and rice (Oryza sativa L.) in annual metric tonne production (FAO, 2009). An assessment of recent trends in genetic improvement of wheat yields is vital to determine whether increased consumption demands of an evergrowing world population will be met.

In the early 1930s, the USDA established, in cooperation with university agricultural experiment stations, cooperative improvement programs in the Great Plains and in other wheat production zones (Reitz and Salmon, 1959). These extant programs include

Published in Crop Sci. 50:1882-1890 (2010).

doi: $10.2135 /$ cropsci2009.11.0685

Published online 23 July 2010.

(C) Crop Science Society of America | 5585 Guilford Rd., Madison, WI 53711 USA

All rights reserved. No part of this periodical may be reproduced or transmitted in any form or by any means, electronic or mechanical, including photocopying, recording, or any information storage and retrieval system, without permission in writing from the publisher. Permission for printing and for reprinting the material contained herein has been obtained by the publisher. 
uniform regional nursery trials, with two major replicated yield trials in the Great Plains, the SRPN and the NRPN (USDA, 2009). Each year, every major Great Plains public and private breeding program enters their highest performing experimental breeding lines. Thus, the entries in general represent the highest current genetic potential for grain yield production, though breeders also must balance their selections to ensure they also meet current needs for traits, such as quality and disease resistance, that might temper yield responses. These trials serve to assess agronomic performance and disease resistance responses of advanced wheat breeding lines over broad geographic areas, and to facilitate the exchange of germplasm among public and private wheat breeding programs. Continued free and open exchange of germplasm remains a vital component of the world's efforts to maintain a food supply for all.

Since 1932, the SRPN and NRPN have included a long-term check, the Crimean variety Kharkof (Reitz and Salmon, 1959). Responses of experimental lines, relative to Kharkof, previously have been used to evaluate genetic improvement over time in grain yield and other agronomic traits. Reitz and Salmon (1959) used data from the Great Plains regional trials conducted from 1932 to 1959 to demonstrate a 10 to $30 \%$ genetic improvement in grain yield of the advanced breeding lines relative to Kharkof. They also noted an improvement in grain volume weight of approximately $6.5 \mathrm{~kg} \mathrm{hL}^{-1}$ over Kharkof. Schmidt (1984) and Peterson et al. (1989) both documented a 30\% improvement in grain yield potential over Kharkof in the SRPN for the time period 1959 to 1984. This value was derived from the mean response of nursery entries; the most productive lines demonstrated a $49 \%$ increase over this same time period. The increase in the NRPN, for the same time period, was more modest; Schmidt (1984) estimated it to be $25 \%$, while Peterson et al. (1989), using data from nine NRPN locations, estimated the improvement as only $14 \%$ above that of Kharkof. Up to 1959, most NRPN entries had similar yield potential to Kharkof (Schmidt, 1984; Peterson et al., 1989). Schmidt (1984) estimated the true annual rate of improvement to be 0.75 to $1.5 \%$ (of Kharkof) for the two nurseries.

An alternative approach to the estimation of genetic gain for grain yield is the conduct of yield trials including entries released at various time periods compared to an historic check variety. Cox et al. (1988) used this procedure to demonstrate a $1.0 \% \mathrm{yr}^{-1}$ genetic gain for grain yield in hard red winter wheats relative to the keystone variety Turkey, over the time period 1919 to 1987. Donmez et al. (2001) estimated genetic gain for yield at only $0.44 \% \mathrm{yr}^{-1}$ in hard winter wheats, also relative to Turkey, over the time period 1873 to 1995. Fufa et al. (2005) used a similar approach with Nebraska-adapted winter wheats, and arrived at a similar estimate for genetic gain in grain yield of $0.48 \% \mathrm{yr}^{-1}$. Khalil et al. (1995) derived a much higher estimate of $>4.0 \% \mathrm{yr}^{-1}$ for genetic gain in grain yield within the Oklahoma State breeding program for the time period 1969 to 1993. A drawback of this approach, however, is that changes in pathogen races over time may negatively impact grain yield of older lines, and inflate the estimate of the relative performance of new cultivars.

Schmidt (1984) had noted that the increases in grain yield potential from 1975 to 1984 in both the SRPN and NRPN had been minimal, and, at that time, suggested that the rate of genetic gain perhaps was slowing, or reaching a plateau. The goal of the present investigation was to examine genetic improvement in winter wheat grain yield in the SRPN and NRPN over the time period 1959 to 2008, to determine whether Schmidt's concerns in 1984 were valid. Furthermore, a separate analysis was conducted to determine whether the rate of change since 1984 has remained constant, or has diminished. Finally, genetic gains or losses, in the additional agronomic traits grain volume weight, plant height, and heading date, also were examined.

\section{MATERIALS AND METHODS}

All data were obtained from annual regional reports of the SRPN and NRPN, now maintained on-line (USDA, 2009). The SRPN, as of 2008, typically contains 45 to 50 entries, including controls, and is grown in replicated yield trials at 30 locations in Texas, New Mexico, Colorado, Oklahoma, Missouri, Kansas, Nebraska, Iowa, Wyoming, and South Dakota. All but five locations are rain-fed. Irrigated trials are planted at Clovis and Farmington, NM; Bushland, TX; Goodland, OK; and Fort Collins, CO. The NRPN generally contains 30 to 35 entries, and is grown at 21 sites in Kansas, Nebraska, Iowa, Wyoming, South Dakota, North Dakota, Minnesota, and Alberta, Canada. Only the Alberta site (Lethbridge) is irrigated. Plot size varies due to differences in local cooperators equipment and procedures. Pathogen control is not practiced. Typically, untreated seed is planted. Since the late 1990s, nearly all experimental entries have been changed each year. Before that time, lines often were entered for two seasons. For each entry, mean data for grain yield, grain volume weight, plant height, and days from 1 January to heading were obtained. Data were converted to relative values by expressing each entry mean as a percentage of the response of Kharkof from the same nursery/ year. Additional check varieties included each year in the nurseries were excluded from the analyses, as they have changed over time. For each nursery and each year, mean relative responses were determined by averaging responses of all included entries. Regression analysis was used to evaluate relationships between relative values and calendar year of nursery. Separate regression analyses were performed, for each nursery, using: (i) all experimental lines, (ii) the entry with the highest regional grain yield (most productive entry $=\mathrm{MP}$ ), and (iii) the five most productive entries (5 MP). Equality of slopes was tested by calculation of student's t statistics (Bethea et al., 1985). Regression analyses were performed for the entire time period from 1959 to 2008, and for the time frames 1959 to 1984 , and 1984 to 2008. The year 1959 was used as the initial year as it was the first year the SRPN and NRPN were grown in their current configurations. 
The year 1984 was selected as the start of the most recent time frame as it represents both the mid-point of the time frame investigated and the culminating year of the investigation of Schmidt (1984). The slopes from regression equations were used to estimate genetic gain as \% (Kharkof) $\mathrm{yr}^{-1}$. Slopes with probability levels $<0.05$ were considered statistically significant. SAS Version 9.1 programs and procedures were used for all statistical analyses (SAS Institute, 2003). SigmaPlot Version 11.0 was used to examine possible fit to nonlinear equations. However, no statistically significant nonlinear models were detected.

\section{RESULTS AND DISCUSSION}

Mean values for grain yield and additional agronomic traits for Kharkof in the SRPN and NRPN over the time period 1959 to 2008 are presented in Table 1. Mean grain yield of Kharkof also is presented as a function of year in Fig. 1 (SRPN) and 2 (NRPN). The wide standard deviations represent site-to-site variation in any given year and are a consequence of the erratic climatic conditions typical of the Great Plains. In the SRPN, there was no significant relationship between absolute grain yield of Kharkof and year. In the NRPN, however, there was a significant positive relationship $\left(r^{2}=0.49, p<0.0001\right)$. This increase in absolute grain yield of Kharkof over time could be a consequence of climatic changes in the northern Great Plains (Easterling, 2002; Feng and $\mathrm{Hu}, 2004)$. Since 1950, these changes have resulted in more favorable moisture regimes, less severe winters with subsequent diminished frequency of winter-kill in winter wheat plantings, and a longer growing season (Easterling, 2002; Feng and Hu, 2004). Morgan et al. (2008) have noted that recent climatic changes in the northern Great Plains will actually enhance plant productivity, as, historically, cold temperatures in spring have been a primary limiting factor. However, study sites in the NRPN have not remained constant over the years. Some drier, less productive locations such as Sheridan and Laramie, WY, and Havre, MT were abandoned, and additional, more productive locations in South Dakota and Nebraska were added over time. Thus, the increase in mean yield of Kharkof over time in the NRPN might be merely a consequence of the use of more favorable locations.

Significant positive linear relationships were observed for relative grain yield as a function of time for all entries, MP and 5MP in the SRPN for the time period 1959 to 2008 (Table 2, Fig. 3). There were no statistically significant differences between the slopes. Slopes for the time period 1959 to 1984 (Table 2) were similar to those observed for the entire time frame, and again there were no differences in the slopes observed for all entries, MP and 5MP. For the time period 1984 to 2008, however, the slopes did not differ significantly from zero for any of the three regressions. For grain volume weight and heading date, some significant negative slopes were observed, but the magnitudes of the changes were of little practical significance (Table 2). For plant height, significant negative slopes were observed for all entries, MP and
Table 1. Mean agronomic characteristics of the long-term check cultivar Kharkof, 1959 to 2008, Southern (SRPN) and Northern Regional Performance Nurseries (NRPN).

\begin{tabular}{lcccc}
\hline \multicolumn{1}{c}{ Nursery } & $\begin{array}{c}\text { Grain } \\
\text { yield }\end{array}$ & $\begin{array}{c}\text { Grain } \\
\text { volume } \\
\text { weight }\end{array}$ & $\begin{array}{c}\text { Days from } \\
\mathbf{1 / 1} \text { to } \\
\text { heading }\end{array}$ & $\begin{array}{c}\text { Plant } \\
\text { height }\end{array}$ \\
\hline SRPN & $\mathrm{kg} \mathrm{ha}^{-1}$ & $\mathrm{~kg} \mathrm{hL}^{-1}$ & & $\mathrm{~cm}$ \\
Mean & 2347 & 74.6 & 143 & 97 \\
Standard Deviation & 299 & 1.5 & 5 & 8 \\
Minimum & 1755 & 71.3 & 134 & 74 \\
Maximum & 2918 & 77.3 & 158 & 113 \\
& & & & \\
NRPN & & & 160 & 96 \\
Mean & 2541 & 75.4 & 8 & 9 \\
Standard Deviation & 451 & 2.9 & 124 & 65 \\
Minimum & 1480 & 62.5 & 180 & 110 \\
Maximum & 3577 & 78.4 & & \\
\hline
\end{tabular}

5MP for the time period 1959 to 2008 (Table 2). The greatest rate of change, however, was observed in the time period 1959 to 1984 (Table 2); from 1984 to 2008, the slopes did not differ significantly from zero.

In the NRPN, there were significant positive relationships between relative grain yield and calendar year of the nursery for all entries, MP and 5MP for the time period 1959 to 2008, and there were no significant differences between the slopes (Table 3, Fig. 4). For the time period 1959 to 1984 , only the slope (0.41) for all entries was significant, and indicative of only a modest rate of progress. Greater progress was made for the time period 1959 to 2008. All entries and 5MP also showed significant positive slopes for the regression of grain yield on year for this more recent time, but the $R^{2}$ values were much lower than observed for the time period 1959 to 2008 (Table 3). For grain volume weight there were significant negative relationships observed only over the time period 1959 to 2008

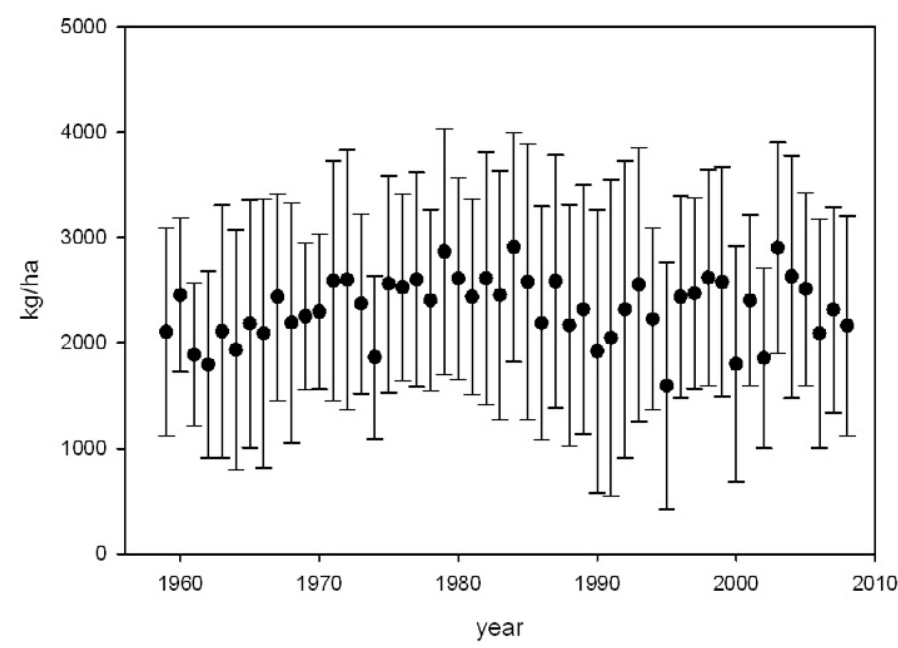

Figure 1. Mean grain yields $\left(\mathrm{kg} \mathrm{ha}^{-1}\right)$ and standard errors of Kharkof, 1959-2008, Southern Regional Performance Nursery. 
Table 2. Regression equations describing relationships between relative (to Kharkof) agronomic traits and year of hard winter wheats entered in the Southern Regional Performance Nursery (SRPN).

\begin{tabular}{|c|c|c|c|c|c|c|}
\hline & Relative trait & Entries $^{\dagger}$ & Regression equation & std error (slope) & $R^{2}$ & $p$ \\
\hline \multirow[t]{12}{*}{ SRPN (1959-2008) } & Grain yield & All & $y=-2009+1.08(y r)$ & 0.12 & 0.64 & $<0.0001$ \\
\hline & & $\mathrm{MP}$ & $y=-2328+1.25(y r)$ & 0.16 & 0.58 & $<0.0001$ \\
\hline & & $5 \mathrm{MP}$ & $y=-2386+1.28(y r)$ & 0.14 & 0.63 & $<0.0001$ \\
\hline & Grain volume weight & All & $y=197.7-0.05(y r)$ & 0.01 & 0.25 & 0.0002 \\
\hline & & $\mathrm{MP}$ & $y=180.9-0.04(y r)$ & 0.02 & 0.07 & 0.075 \\
\hline & & $5 \mathrm{MP}$ & $y=195.9-0.05(y r)$ & 0.02 & 0.17 & 0.003 \\
\hline & Days-to-heading & All & $y=146.5-0.03(y r)$ & 0.02 & 0.06 & 0.086 \\
\hline & & MP & $y=192.4-0.05(y r)$ & 0.02 & 0.13 & 0.01 \\
\hline & & $5 \mathrm{MP}$ & $y=186.4-0.05(y r)$ & 0.01 & 0.19 & 0.002 \\
\hline & Plant height & All & $y=712.4-0.32(y r)$ & 0.05 & 0.49 & $<0.0001$ \\
\hline & & $\mathrm{MP}$ & $y=776.8-0.33(y r)$ & 0.07 & 0.37 & $<0.0001$ \\
\hline & & $5 \mathrm{MP}$ & $y=731.1-0.33(y r)$ & 0.06 & 0.42 & $<0.0001$ \\
\hline \multirow[t]{12}{*}{ SRPN (1959-1984) } & Grain yield & All & $y=-1570+0.86(y r)$ & 0.25 & 0.34 & 0.0018 \\
\hline & & $\mathrm{MP}$ & $y=-1497+0.83(y r)$ & 0.38 & 0.18 & 0.04 \\
\hline & & $5 \mathrm{MP}$ & $y=-1164+0.91(y r)$ & 0.29 & 0.29 & 0.005 \\
\hline & Grain volume weight & All & $y=225.4-0.06(y r)$ & 0.03 & 0.14 & 0.06 \\
\hline & & $\mathrm{MP}$ & $y=354.8-0.13(y r)$ & 0.06 & 0.16 & 0.05 \\
\hline & & $5 \mathrm{MP}$ & $y=368.2-0.14(y r)$ & 0.04 & 0.29 & 0.004 \\
\hline & Days-to-heading & All & $y=110.8-0.007(y r)$ & 0.05 & 0.001 & 0.87 \\
\hline & & $\mathrm{MP}$ & $y=195.4-0.05(y r)$ & 0.05 & 0.04 & 0.35 \\
\hline & & $5 \mathrm{MP}$ & $y=154.0-0.05(y r)$ & 0.04 & 0.02 & 0.49 \\
\hline & Plant height & All & $y=1705.6-0.82(y r)$ & 0.11 & 0.71 & $<0.0001$ \\
\hline & & $\mathrm{MP}$ & $y=1934.0-0.94(y r)$ & 0.17 & 0.56 & $<0.0001$ \\
\hline & & $5 \mathrm{MP}$ & $y=1932-0.94(y r)$ & 0.14 & 0.64 & $<0.0001$ \\
\hline \multirow[t]{12}{*}{ SRPN (1984-2008) } & Grain yield & All & $y=-1336+0.75(y r)$ & 0.41 & 0.13 & 0.08 \\
\hline & & MP & $y=-1417+0.80(y r)$ & 0.48 & 0.11 & 0.11 \\
\hline & & $5 \mathrm{MP}$ & $y=-1337+0.76(y r)$ & 0.47 & 0.10 & 0.13 \\
\hline & Grain volume weight & All & $y=271.0-0.09(y r)$ & 0.03 & 0.22 & 0.02 \\
\hline & & $\mathrm{MP}$ & $y=233.3-0.07(y r)$ & 0.06 & 0.06 & 0.25 \\
\hline & & $5 \mathrm{MP}$ & $y=250.0-0.07(y r)$ & 0.04 & 0.12 & 0.09 \\
\hline & Days-to-heading & All & $y=20.4+0.04(y r)$ & 0.03 & 0.06 & 0.22 \\
\hline & & $\mathrm{MP}$ & $y=56.9+0.02(y r)$ & 0.05 & 0.01 & 0.70 \\
\hline & & $5 \mathrm{MP}$ & $y=113.7-0.01(y r)$ & 0.03 & 0.01 & 0.76 \\
\hline & Plant height & All & $y=-10.0+0.5(y r)$ & 0.09 & 0.01 & 0.61 \\
\hline & & $\mathrm{MP}$ & $y=56.7+0.01(y r)$ & 0.13 & 0.01 & 0.94 \\
\hline & & $5 \mathrm{MP}$ & $y=127.8+0.09(y r)$ & 0.09 & 0.01 & 0.79 \\
\hline
\end{tabular}

${ }^{\dagger}$ Entries: all = all entries in each trial included; MP = most productive (grain yield) entry alone included in model; 5MP = highest five yielding entries included.

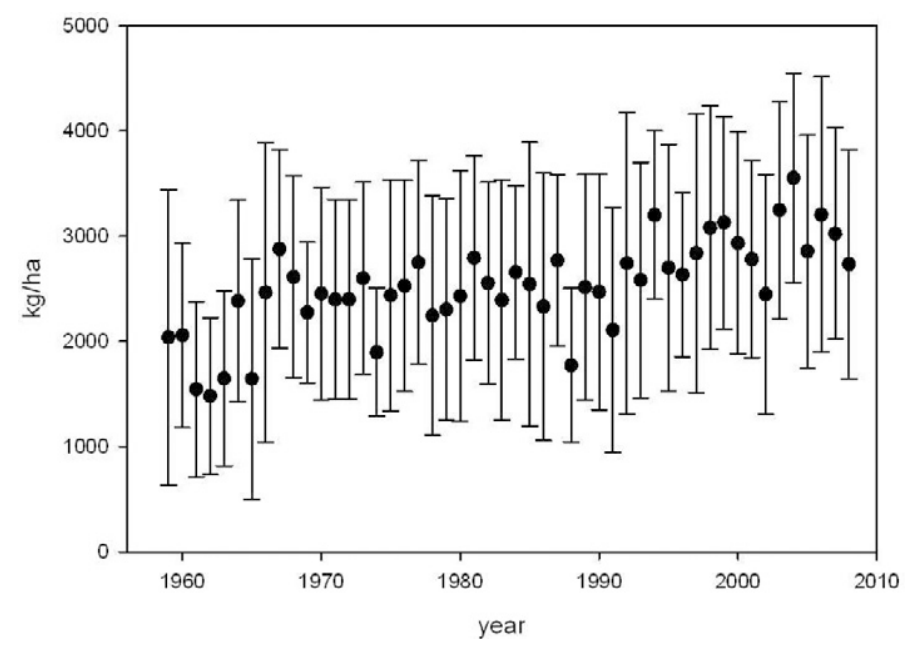

Figure 2. Mean grain yields $\left(\mathrm{kg} \mathrm{ha}^{-1}\right)$ and standard errors of Kharkof, 1959-2008, Northern Regional Performance Nursery. for all entries, MP and 5MP, and again no differences in slopes. For days-to-heading, all entries and 5MP showed significant negative relationships over the time period 1959 to 2008, but only MP showed a significant relationship over the time period 1984 to 2008. Plant height showed significant negative slopes for all three classes for all time periods, and there were no significant differences in the slopes.

Using the slopes from regression, estimates of genetic gain (as percent of Kharkof) for the time period 1959 to 2008 in grain yield in the SRPN ranged from $1.1 \% \mathrm{yr}^{-1}$ for all entries to $1.3 \% \mathrm{yr}^{-1}$ for MP or $5 \mathrm{MP}$. No significant differences were detected in the slopes. In the NRPN, genetic gains in grain yield were lower, ranging from $0.79 \% \mathrm{yr}^{-1}$ for both all entries and for MP to $0.85 \% \mathrm{yr}^{-1}$ for $5 \mathrm{MP}$. Again, there were no significant differences detected in the slopes. In both nurseries, annual genetic losses in grain volume weight and 
Table 3. Regression equations describing relationships between relative (to Kharkof) agronomic traits and year of hard winter wheats entered in the Northern Regional Performance Nursery.

\begin{tabular}{|c|c|c|c|c|c|c|}
\hline & Relative trait & Entries $^{\dagger}$ & Regression equation & std error (slope) & $R^{2}$ & $p$ \\
\hline \multirow[t]{12}{*}{ NRPN (1959-2008) } & Grain yield & All & $y=-1455+0.79(y r)$ & 0.09 & 0.63 & $<0.001$ \\
\hline & & MP & $y=-1478+0.79(y r)$ & 0.14 & 0.44 & $<0.001$ \\
\hline & & $5 \mathrm{MP}$ & $y=-1568+0.86(y r)$ & 0.11 & 0.55 & $<0.001$ \\
\hline & Grain volume weight & All & $y=290.0-0.10(y r)$ & 0.02 & 0.31 & $<0.001$ \\
\hline & & MP & $y=341.7-0.13(y r)$ & 0.03 & 0.30 & $<0.0001$ \\
\hline & & $5 \mathrm{MP}$ & $y=338.1-0.12(y r)$ & 0.02 & 0.38 & $<0.0001$ \\
\hline & Days-to-heading & All & $y=148.9-0.03(y r)$ & 0.01 & 0.13 & 0.01 \\
\hline & & MP & $y=142.6-0.02(y r)$ & 0.01 & 0.08 & 0.05 \\
\hline & & $5 \mathrm{MP}$ & $y=145.7-0.02(y r)$ & 0.01 & 0.11 & 0.02 \\
\hline & Plant height & All & $y=924.6-0.42(y r)$ & 0.04 & 0.72 & $<0.001$ \\
\hline & & MP & $y=840.6-0.38(y r)$ & 0.05 & 0.55 & $<0.001$ \\
\hline & & $5 \mathrm{MP}$ & $y=900.9-0.41(y r)$ & 0.04 & 0.68 & $<0.001$ \\
\hline \multirow[t]{12}{*}{ NRPN (1959-1984) } & Grain yield & All & $y=-691+0.41(y r)$ & 0.19 & 0.17 & 0.04 \\
\hline & & MP & $y=-111+0.11(y r)$ & 0.35 & 0.01 & 0.74 \\
\hline & & $5 \mathrm{MP}$ & $y=-378+0.25(y r)$ & 0.26 & 0.04 & 0.35 \\
\hline & Grain volume weight & All & $y=241.8-0.07(y r)$ & 0.07 & 0.04 & 0.33 \\
\hline & & MP & $y=486.5-0.20(y r)$ & 0.09 & 0.18 & 0.04 \\
\hline & & $5 \mathrm{MP}$ & $y=358.9-0.13(y r)$ & 0.07 & 0.11 & 0.10 \\
\hline & Days-to-heading & All & $y=234.7-0.07(y r)$ & 0.02 & 0.31 & 0.004 \\
\hline & & MP & $y=124.9-0.01(y r)$ & 0.03 & 0.01 & 0.68 \\
\hline & & $5 \mathrm{MP}$ & $y=217.4-0.06(y r)$ & 0.02 & 0.23 & 0.02 \\
\hline & Plant height & All & $y=1619-0.77(y r)$ & 0.08 & 0.82 & $<0.001$ \\
\hline & & MP & $y=1706-0.82(y r)$ & 0.12 & 0.66 & $<0.001$ \\
\hline & & $5 \mathrm{MP}$ & $y=1578-0.75(y r)$ & 0.08 & 0.78 & $<0.001$ \\
\hline \multirow[t]{12}{*}{ NRPN (1984-2008) } & Grain yield & All & $y=-1533.0+0.83(y r)$ & 0.28 & 0.28 & 0.01 \\
\hline & & MP & $y=-1303.5+0.73(y r)$ & 0.37 & 0.15 & 0.06 \\
\hline & & $5 \mathrm{MP}$ & $y=-1311.3+0.73(y r)$ & 0.32 & 0.18 & 0.03 \\
\hline & Grain volume weight & All & $y=205.8-0.05(y r)$ & 0.03 & 0.12 & 0.09 \\
\hline & & MP & $y=161.7-0.03(y r)$ & 0.06 & 0.01 & 0.59 \\
\hline & & $5 \mathrm{MP}$ & $y=225.8-0.06(y r)$ & 0.03 & 0.11 & 0.11 \\
\hline & Days-to-heading & All & $y=211.9-0.06(y r)$ & 0.03 & 0.16 & 0.05 \\
\hline & & $\mathrm{MP}$ & $y=222.2-0.06(y r)$ & 0.03 & 0.17 & 0.04 \\
\hline & & $5 \mathrm{MP}$ & $y=159.9-0.03(y r)$ & 0.03 & 0.05 & 0.28 \\
\hline & Plant height & All & $y=969.3-0.44(y r)$ & 0.1 & 0.46 & $<0.001$ \\
\hline & & MP & $y=1108.5-0.50(y r)$ & 0.11 & 0.51 & $<0.001$ \\
\hline & & $5 \mathrm{MP}$ & $y=855.6-0.39(y r)$ & 0.11 & 0.34 & $<0.001$ \\
\hline
\end{tabular}

${ }^{\dagger}$ Entries: all = all entries in each trial included; MP = most productive (grain yield) entry alone included in model; 5MP = highest five yielding entries included.

days from $1 / 1$ to heading were slight, with the exception of grain volume weight in the NRPN. In this nursery, relative grain volume weight declined, since 1959, at a rate of $0.13 \%$ $\mathrm{yr}^{-1}$. This translates, over a $50-\mathrm{yr}$ period, to approximately a $6 \%$ loss relative to Kharkof. Evidently, selection for grain yield has resulted in a slight decline in grain volume weight over time. Most of this decline, however, occurred before 1984. Breeding programs have not managed to maintain the improvement in grain volume weight reported by Reitz and Salmon (1959) over the time period 1932 to 1959. Genetic loss in plant height was similar in the two nurseries, with estimates ranging from -0.32 to $-0.33 \% \mathrm{yr}^{-1}$ in the SRPN, and from -0.37 to $-0.43 \% \mathrm{yr}^{-1}$ in the NRPN.

As the slope from regression of grain yield in the SRPN for the time period 1984 to 2008 did not differ significantly from zero, no genetic gain can be estimated for this time-frame. In the NRPN, the slope did differ significantly from zero for all entries and 5MP, but the $R^{2}$ values were low, only 0.28 and 0.37 , respectively. Using the slopes from regression, genetic gain in the NRPN since 1984 can be estimated as 0.73 to $0.83 \% \mathrm{yr}^{-1}$. However, the high std errors associated with the slopes, and the low $R^{2}$ values, do little to ensure confidence in these estimates.

The observed estimates of genetic gain in grain yield in this study are similar to those reported by other researchers for Great Plains winter wheats (Schmidt, 1984; Cox et al., 1988; Donmez et al., 2001) with most figures approximating a yield gain of $1.0 \%$ (of controls) per year. The estimates of Donmez et al. (2001) and Fufa et al. (2005) were however, both $<0.5 \% \mathrm{yr}^{-1}$. Both Donmez et al. (2001) and Fufa et al. (2005) used the cultivar Turkey, and the year of its introduction to the United States, 1874, 

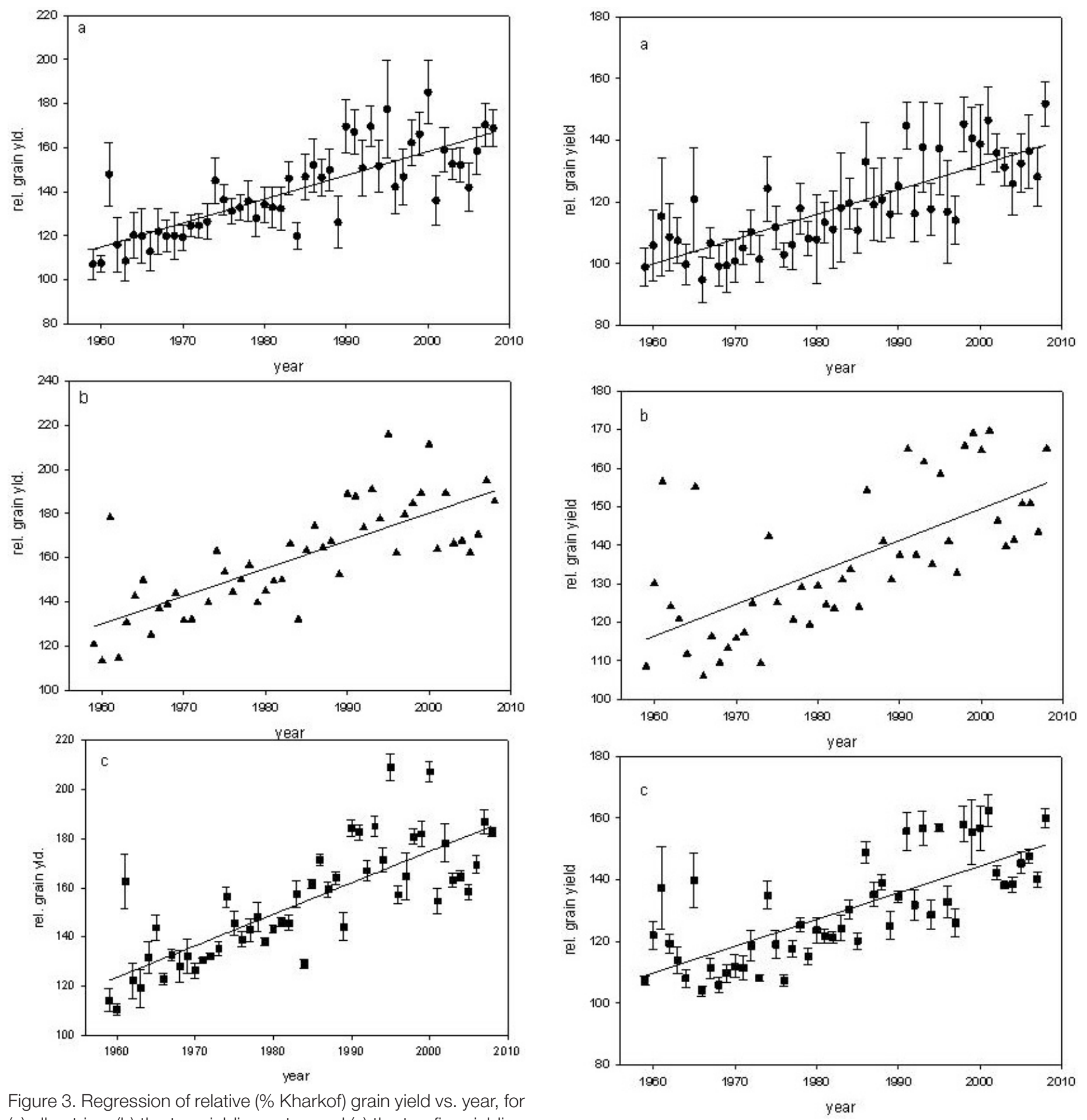

Figure 3. Regression of relative (\% Kharkof) grain yield vs. year, for (a) all entries, (b) the top yielding entry, and (c) the top five yielding entries, Southern Regional Performance Nursery, 1959 to 2008.

as their starting date. Little breeding work was conducted in the Great Plains from the time of Turkey's introduction until the 1920s (Reitz and Heyne, 1944), and Turkey essentially has the same yield potential as Kharkof. Extending the time period $50 \mathrm{yr}$ before the commencement of organized breeding efforts, therefore, depresses the estimates of genetic gain from selection and breeding.

Schmidt (1984) and Peterson et al. (1989) similarly observed that genetic gain for grain yield in the NRPN

Figure 4. Regression of relative (\% Kharkof) grain yield vs. year, for (a) all entries, (b) the top yielding entry, and (c) the top five yielding entries, Northern Regional Performance Nursery, 1959 to 2008.

was less than that observed in the SRPN. Schmidt (1984) suggested this was due to harsher environmental conditions especially during dormant winter months in the region which rendered selection of improved types more difficult. Reitz and and Salmon (1959) had noted that none of the new wheats tested in the time period 1932 to 1959 possessed the winter hardiness of Kharkof. This would suggest that breeders in the northern Great Plains started at a 
deficit in the early 1960s in terms of winter survival potential relative to Kharkof. However, the past 25 yr have seen relatively mild winters in the region, with little reported winterkill. The greater slope observed in the regression of relative grain yield on nursery year observed in the NRPN for the time period 1984 to 2008 , compared to that observed for the first $25 \mathrm{yr}$ of this study, might be a consequence of less severe winterkill in the region. Milder winters might have allowed breeders access to a wider pool of adapted materials. Another factor contributing to the lower genetic gain in the NRPN, relative to that observed in the SRPN, is that the majority of entries in this trial historically was derived from only two breeding programs, that of the University of Nebraska and South Dakota State University. In the SRPN, far more breeding programs have been active, and the difference between gain in the two nurseries might merely be a consequence of the level of genetic diversity evaluated. Also, in terms of its phenological development, Kharkof is very likely most highly adapted to latitudes similar to the winter wheat growing regions of Nebraska and South Dakota. Thus, NRPN entries must out-yield a welladapted variety to show progress; SRPN breeders have had a comparatively easier task, namely, that of besting a wheat ill-adapted to their home latitudes. Finally, the available gene pool of wheats capable of surviving winters in the northern Great Plains might be narrow, thereby limiting the rate of progress in the NRPN.

As the regional nursery entries derive from breeding programs in many states, the present investigation might provide underestimates of genetic gain. Breeders of late may have focused more on breeding for specific adaptation, rather than adaptation to broad geographic regions. At any given location, the trial does contain breeding materials of less than optimal adaptation. This could depress location means, relative to those that might be observed if only perfectly adapted materials were used. However, several observations suggest such objections are unwarranted. Estimates of genetic gain using MP or $5 \mathrm{MP}$ were not significantly different from those of all entries in either nursery. In addition, data from state variety trials, such as the University of Nebraska Winter Wheat Variety tests (UNL, 2009), can be used to obtain estimates of relative performance of highly adapted materials, relative to the long-term check Turkey, a line with yield potential similar to that of Kharkof. For the most recent $2-\mathrm{yr}$ mean data reported, mean performance relative to Turkey for rainfed sites in the South East, South Central, West Central and Western reporting districts of Nebraska was, respectively, 120, 156, 133, and 118\% (UNL, 2009). Respective values for the same zones using the MP cultivars were: 144 , 195,148 , and $132 \%$. These values when averaged translate into lower average estimates of genetic gain than observed in the regional nursery materials reported herein.

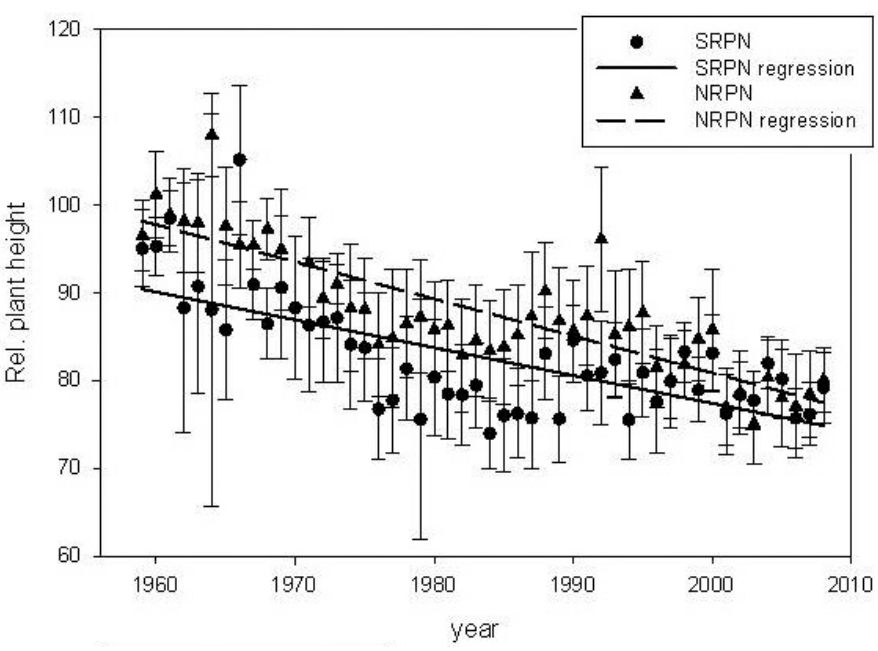

Figure 5. Mean relative plant heights, Southern Regional Performance Nursery (SRPN) and Northern Regional Performance Nursery (NRPN), 1959 to 2008.

The observed genetic loss in plant heights is a consequence of the adaptation, commencing in the 1960s, of shorter stature semi-dwarf wheats (Schmidt, 1984). Most of the change in the trait, however, in the SRPN, was accomplished by the early 1980s (Fig. 5). Indeed, there was no significant relationship observed when plant height was regressed on year for the time period 1984 to 2008 in the SRPN (Table 2). In the NRPN, the trend toward shorter wheats continues (Fig. 5, Table 3), with significant negative relationships still observed for the time period 1984 to 2008, though a greater rate of change was observed in the earlier time period. In this region, genetically determined tall wheats still have been favored by growers in the drier northwest areas. The tall wheats display greater capacity for fall emergence, and provide adequate height, under the prevalent dry conditions, for mechanical harvest operations. Nonetheless, average plant heights still are on the decline in the NRPN.

Schmidt (1984) addressing the question "have crop yields peaked?" noted that genetic improvement in wheat yield in the time period 1975 to 1984 had been minimal. Data from the present investigation suggest that, if genetic gain for wheat yield has not yet peaked, it shall do so shortly, unless there is another major leap forward in grain yield potential. In Schmidt's report, relative grain yield of all entries and the MP entry in the SRPN had reached 130 and $149 \%$, respectively, that of Kharkof by 1984 . For the last 3 yr (2006-2008) used in the present study, the observed respective mean values for the same two classes were 165 and 183\%. However, Fig. 2 demonstrates that these same values were attained by entries in the SRPN by the early 1990s. In addition, since 1984, there was no significant slope in the regression of relative grain yield on calendar year. In the NRPN, the relative grain yield of all entries in 1984 was approximately 125\% that of Kharkof (Schmidt, 1984; Peterson et al., 1989). For the last $3 \mathrm{yr}$ (2006-2008) of this study, the mean value was 139\%, but 
again, this value had been achieved by nursery entries as early as 1990. While there remained a significant positive slope for the regression of relative grain yield on year in the NRPN since 1984, the $R^{2}$ value was only 0.28 , indicating a very poor goodness of fit. Examination of the distributions of relative grain yields in the time period 1984 to 2008 (Fig. 3 and 4) suggests a plateau has been reached, with year-to-year observations being nothing more than random fluctuations about a mean value.

Since inception of modern breeding efforts, genetic improvement for wheat grain yield in the Great Plains has been propelled by three significant movements (Schmidt, 1984). First, as noted by Reitz and Salmon (1959), breeders in the region developed wheats with maturities proper for their respective latitudes. Essentially, the early wheat breeders in the region converted an un-adapted crop into an adapted one. The second leap forward was the introduction of stem rust (Puccinia graminis Pers.:Pers. f. sp. tritici Eriks. E. Henn.) resistance in the 1960s. Before that decade, stem rust had been a perennial depressant of grain yields, but in the past $40 \mathrm{yr}$ deployment of resistant varieties and eradication of the alternate host for the sexual phase of the pathogen have reduced its impact. Finally, the introduction of semi-dwarfing genes, with a subsequent change in harvest index, commencing in the 1960s, led to significant improvements in grain yield. Since that time, however, there has been no additional "great leap forward." Hybrid wheat was suggested and tried as a possible means of genetically enhancing grain yield (Peterson et al., 1997; Koemel et al., 2004), but economic factors prevented the technology from ever impacting wheat production and breeding in the Great Plains. The introduction of chromosomal materials from rye (Secale cereale L), largely in the form of 1AL.1RS or 1BL.1RS wheat-rye chromosomal translocations, showed some potential for yield improvement in the region (Carver and Rayburn, 1994; Moreno-Seville et al., 1995a, 1995b). However, yield-enhancing effects of these translocations were not evident in all genetic backgrounds (Moreno-Seville et al., 1995a; McKendry et al., 1996) and negative effects on quality, especially with 1BL.1RS materials, limited their utility (Graybosch, 2001).

Several factors may contribute to the diminished rate of grain yield improvement in the Great Plains since 1984. Breeders in the region wage perpetual warfare against pathogens, with leaf rust (Puccinia triticina Eriks.) being the primary foe. Newly deployed resistance genes often are overcome by the rapid rate of new race development in this pathogen (Kolmer et al., 2009). Stripe or yellow rust (Puccinia striiformis Westend.), which, in the years before 2000 was rarely seen in the region, has now become more prevalent with the evolution of new races and shifting climatic patterns (Chen, 2005). New germplasm must be assessed in regional breeding programs to counter this nascent disease problem. Breeders in the region also must anticipate the arrival of new forms of old diseases, for example, stem rust race Ug99 (Jin and Singh, 2006). The challenge of combining genes from various sources to deriving new germplasm with the required resistance genes to rusts and other pathogens can limit the rate of genetic progress for grain yield, per se, especially if programs must continuously access nonadapted sources of resistance. Finally, a trend toward the development of hard white wheats in the region (Morris and Paulsen, 1992), which commenced in the 1980s, may have limited progress, as breeders again accessed nonadapted sources of germplasm for the required quality traits. However, white wheats have never comprised more than $10 \%$ of the nursery entries in any given year.

If indeed genetic improvement for wheat grain yield has slowed or peaked in the Great Plains any further increase in the supply of wheat from the region can only derived from the application of techniques to enhance production. Cassman (1999) noted that worldwide wheat supplies could only meet increased demands via "ecological intensification" of production systems. However, adaptation of currently available production techniques on a wider scale could boost absolute wheat productivity from the Great Plains. In some states, such as Nebraska, wheat production is most common in the drier western regions, and most of the crop is produced under rainfed conditions. More productive land in the eastern portion of the state, where rainfall potential is higher, or has access to irrigation, is used to produce maize (Zea mays L.) or soybean (Glycine max L.). Use of these more productive areas for wheat production could, temporarily at least, continue to meet world demands for wheat. In the long term, however, effective strategies to increase the genetic gain for wheat grain yield must be identified.

\section{Acknowledgments}

The authors wish to thank the hundreds of wheat researchers who have participated in the NRPN and SRPN programs over the past 50 years. They specifically would like to acknowledge Bob Divoky, Kyle Ditch, and Lori Divis for their diligence in ensuring accurate distribution of nursery seed each and every year. They also thank Brigid Amos for assistance with SigmaPlot. Finally, this manuscript is dedicated to the memory of John Schmidt, Virgil Johnson, and Paul Mattern.

\section{References}

Bethea, R.M., B.S. Duran, and T.L. Boullion. 1985. Statistical methods for engineers and scientists. Marcel Dekker, New York.

Carver, B.F., and A.L. Rayburn. 1994. Comparison of related wheat stocks possessing 1B or 1RS.1BL chromosomes: Agronomic performance. Crop Sci. 34:1505-1510.

Cassman, K.G. 1999. Ecological intensification of cereal production systems: Yield potential, soil quality and precision agriculture. Proc. Natl. Acad. Sci. USA 96:5952-5959.

Cox, T.S., R. Shroyer, L. Ben-Hui, R.G. Sears, and T.J. Martin. 1988. Genetic improvement in agronomic traits of hard red winter wheat cultivars from 1919 to 1987. Crop Sci. 28:756-760. 
Chen, X.M. 2005. Epidemiology and control of stripe rust (Puccinia striiformis f. sp. tritici) on wheat. Can. J. Plant Pathol. 27:314-337.

Donmez, E., R.G. Sears, J.P. Shroyer, and G.M. Paulsen. 2001. Genetic gain in yield attributes of winter wheat in the Great Plains. Crop Sci. 41:1412-1419.

Easterling, D.R. 2002. Recent changes in frost days and the frostfree season in the United States. Bull. Am. Meteorol. Soc. 83:1327-1332.

FAO. 2009. FAOSTAT. Food and agricultural commodities production. Available at http://faostat.fao.org/site/339/default. aspx (verified 29 June 2010). FAO, Rome, Italy.

Feng, S., and Q. Hu. 2004. Changes in agro-meteorological indicators in the contiguous United States: 1951-2000. Theor. Appl. Climatol. 78:247-264.

Feyerherm, A.M., G.M. Paulsen, and J.L. Sebaugh. 1984. Contribution of genetic improvement to recent wheat yield increases in the USA. Agron. J. 76:985-990.

Fufa, H., P.S. Baenziger, B.S. Beecher, R.A. Graybosch, K.M. Eskridge, and L.A. Nelson. 2005. Genetic improvement tends in agronomic performances and end-use quality characteristics among hard red winter wheat cultivars in Nebraska. Euphytica 144:187-198.

Graybosch, R.A. 2001. Uneasy unions: Quality effects of rye chromatin transfers to wheat. J. Cereal Sci. 33:3-16.

Jin, Y., and R.P. Singh. 2006. Resistance in U.S. wheat to recent eastern African isolates of Puccinia graminis f. sp. tritici with virulence to resistance gene Sr31. Plant Dis. 90:476-480.

Khalil, I.H., B.F. Carver, and E.L. Smith. 1995. Genetic gains in two selection phases of a wheat-breeding program. Plant Breed. 114:117-120.

Koemel, J.E., Jr., A.C. Guenzi, B.F. Carver, M.E. Payton, G.H. Morgan, and E.L. Smith. 2004. Hybrid and pureline hard winter wheat yield and stability. Crop Sci. 44:107-113.

Kolmer, J.A., D.L. Long, and M.E. Hughes. 2009. Physiologic specialization of Puccinia triticina on wheat in the United States in 2007. Plant Dis. 93:538-544.

McKendry, A.L., D.N. Tague, P.L. Finney, and K.E. Miskin. 1996. Effect of 1BL.1RS on milling and baking quality of soft red winter wheat. Crop Sci. 36:848-851.

Moreno-Seville, B., P.S. Baenziger, C.J. Peterson, R.A. Graybosch, and D.J. McVey. 1995a. The 1BL/1RS translocation:
Agronomic performance of F3-derived lines from a winter wheat cross. Crop Sci. 35:1051-1055.

Moreno-Seville, B., P.S. Baenziger, D.R. Shelton, R.A. Graybosch, and C.J. Peterson. 1995b. Agronomic performance and end-use quality of $1 \mathrm{~B}$ and $1 \mathrm{~B} / 1 \mathrm{R}$ genotypes derived from the winter wheat Rawhide. Crop Sci. 35:1607-1612.

Morgan, J.A., J.D. Derner, D.G. Milchunas, and E. Pendall. 2008. Management implications of global change for Great Plains rangelands. Rangelands 30:18-22.

Morris, C.F., and G.L. Paulsen. 1992. Review: Research on pre-harvest sprouting resistance in hard red and white winter wheats at Kansas State University. p. 113-120. In M.K. Walker-Simmons and J.L. Reid (ed.) Pre-harvest sprouting in cereals 1992. Am. Assoc. of Cereal Chemists, St. Paul, MN.

Peterson, C.J., V.A. Johnson, J.W. Schmidt, and R.F. Mumm. 1989. Genetic improvement and variability in wheat yields in the Great Plains. p. 175-184. In J.R. Anderson and P.B.R. Hazell (ed.) Variability in grain yields: Implications for agricultural research and policy in developing countries. Johns Hopkins Univ. Press, Baltimore, MD.

Peterson, C.J., J.M. Moffatt, and J.R. Erickson. 1997. Yield stability of hybrid vs. pureline hard winter wheats in regional performance trials. Crop Sci. 37:116-120.

Reitz, L., and E.G. Heyne. 1944. Wheat planting and wheat improvement in Kansas. Thirty-Third Biennial Report of the Kansas State Board of Agriculture, Contribution no. 350. Dep. of Agronomy, Kansas Agric. Exp. Stn., Manhattan, KS.

Reitz, L.P., and S.C. Salmon. 1959. Hard red winter wheat improvement in the plains: A 20-year summary. Tech. Bull. 1192. USDA. U.S. Gov. Print. Office, Washington, DC.

SAS Institute. 2003. 9.1 Foundation for 64-bit Microsoft ${ }^{\circledR}$ Windows ${ }^{\circledR}$, Copyright $(C)$ 2003. SAS Inst., Cary, NC.

Schmidt, J.W. 1984. Genetic contributions to yield gains in wheat. p. 89-101. In W.R. Fehr (ed.) Genetic contributions to yield gains of five major crop plants. ASA and CSSA, Madison, WI.

UNL. 2009. Variety testing. Available at http://varietytest.unl.edu/ index.html (verified 29 June 2010). Univ. of Nebraska, Lincoln.

USDA. 2009. Hard winter wheat regional nurseries. Available at http://www.ars.usda.gov/Research/docs.htm?docid=11932 (verified 29 June 2010). USDA, ARS, Beltsville, MD. 